\title{
PENGARUH UKURAN PERUSAHAAN, PROFITABILITAS, DAN LIKUIDITAS TERHADAP CORPORATE SOCIAL
}

\section{RESPONSIBILITY DISCLOSURE}

\author{
Mega Sekarwigati, Bahtiar Effendi \\ Fakultas Ekonomi, Bisnis dan Ilmu Sosial, Universitas Matana \\ E-mail: bahtiar.effendi@matanauniversity.ac.id
}

\begin{abstract}
This research purposes to check the effects of Company Size and Financial Performance on Corporate Social Responsibility Disclosure. This research uses mining companies which is listed in Bursa Efek Indonesia (BEI) within the period of 2014-2016 as the sample. The total number of companies used as a sample is 14 companies with 3 years of observation. The result of simultant test, company size, profitability, and liquidity has an impact on CSRD. While the result of $t$ test showed a significant negative impact of company size and liquidity on CSRD. While profitability has shown no effect on CSRD.
\end{abstract}

Keywords : Company Size, Profitability, Liquidity, and Corporate Social Responsibility Disclosure.

\section{Pendahuluan}

Corporate Social Responsibility merupakan suatu konsep bahwa organisasi, dalam hal ini lebih dispesifikkan kepada perusahaan memiliki sebuah tanggung jawab sosial terhadap konsumen, karyawan, pemegang saham, komunitas, dan lingkungan dalam segala aspek operasional perusahaan. Corporate Social Responsibility menekankan bahwa tanggung jawab perusahaan bukan lagi sekedar kegiatan ekonomi, yang menciptakan profit demi kelangsungan usaha, tapi juga tanggung jawab sosial dan lingkungan (Dwi dan Maksum, 2008). Menurut Oktafiani dan Rizki (2015), berdirinya perusahaan di lingkungan masyarakat akan memberikan pengaruh terhadap kehidupan di sekitarnya baik secara ekonomi, sosial dan ekologi. Secara ekonomi keberadaan industri akan memberikan kesempatan kerja bagi masyarakat sehingga diharapkan dapat meningkatkan kesejahteraan hidup. Sedangkan secara sosial akan berdampak pada perubahaan perilaku sosial kemasyarakatan, dan secara ekologi akan berpengaruh terhadap pencemaran lingkungan yang diakibatkan oleh limbah pabrik, yang dapat menimbulkan polusi. Khusus untuk ekologi, Effendi,et.al. (2012) menyampaikan bahwa praktik CSR melalui kinerja dan pengungkapan lingkungan di dalamnya menjadikan perusahaan memperoleh manfaat positif dari masyarakat yakni perhatian, kepercayaan dan dukungan penuh untuk melaksanakan kegiatan produksinya guna mencapai going concern. Oleh sebab itu untuk mencapai trust masyarakat, maka sudah sepatutnya jajaran dewan komisaris baik terkait dengan ukuran maupun intensitas rapat dapat menentukan keberhasilan praktik CSR khususnya dalam sisi ekologi (Effendi, 2018).

Tidak dapat dipungkiri bahwa perusahaan pertambangan juga merupakan bagian dari lingkungan dan masyarakat di sekitarnya. Terutama bagi perusahaan yang aktivitasnya mengeksplorasi sumber daya alam, seperti perusahaan pertambangan. Aktivitas perusahaan pertambangan secara langsung dapat berdampak negatif terhadap lingkungan, seperti masalah limbah dan polusi. Hal tersebut menyebabkan perusahaan pertambangan memiliki tingkat 
risiko industri dan lingkungan yang tinggi (Oktariani, 2013). Hal ini sebagaimana sesuai dengan isi pasal 74 Undang-undang No. 40 Tahun 2007 tentang Perseroan Terbatas, tanggung jawab sosial, dan lingkungan sumber daya alam dan tidak dibatasi kontribusinya serta dimuat dalam laporan keuangan. Juga terdapat dalam pasal 15, 17, dan 34 Undangundang No.25 Tahun 2007 tentang Penanaman Modal. Undang-undang tersebut mewajibkan industri atau korporasi-korporasi untuk melaksanakannya, tetapi kewajiban ini bukan merupakan suatu beban yang memberatkan. Pembangunan suatu negara bukan hanya menjadi tanggung jawab pemerintah dan industri saja, tetapi setiap manusia juga berperan untuk mewujudkan kesejahteraan sosial dan pengelolaan kualitas hidup masyarakat. Kini dunia usaha tidak lagi hanya memperhatikan catatan keuangan perusahaan semata (single bottom line), melainkan sudah meliputi keuangan, sosial, dan aspek lingkungan (triple bottom line). Sinergi tiga elemen ini merupakan kunci dari konsep pembangunan berkelanjutan (Rina Dwi Haryani, 2015).

Ukuran perusahaan merupakan variabel yang banyak digunakan untuk menjelaskan pengungkapan sosial yang dilakukan perusahaan dalam laporan tahunan yang dibuat. Secara umum perusahaan besar akan mengungkapkan informasi lebih banyak daripada perusahaan kecil. Hal ini karena perusahaan besar akan menghadapi resiko politis yang lebih besar dibanding perusahaan kecil. Secara teoritis perusahaan besar tidak akan lepas dari tekanan politis, yaitu tekanan untuk melakukan pertanggungjawaban sosial. Pengungkapan sosial yang lebih besar merupakan pengurangan biaya politis bagi perusahaan (Hasibuan, 2001). Pengungkapan yang lebih luas terutama pengungkapan lingkungan guna menunjukkan legitimasi dari ukuran suatu perusahaan kepada para pemangku kepentingan publik sebagai cara untuk memastikan operasi mereka berkesinambungan (Effendi, 2018). Ukuran perusahaan dapat didasari pada jumlah aktiva (aktiva tetap, tidak berwujud, dan lain-lain), jumlah tenaga kerja, volume penjualan, dan kapitalisasi pasar (Cahyonowati dan Purnasiwi, 2011).

Profitabilitas diartikan sebagai kemampuan perusahaan untuk menghasilkan laba dalam upaya meningkatkan nilai pemegang saham. Profitabilitas merupakan ukuran efektifitas perusahaan di dalam menghasilkan keuntungan dengan memanfaatkan aktiva yang dimilikinya. Rasio ini merupakan rasio yang terpenting untuk mengetahui profitabilitas suatu perusahaan. Pengungkapan mengenai pertanggungjawaban sosial perusahaan mencerminkan suatu pendekatan perusahaan dalam melakukan adaptasi dengan lingkungan yang dinamis dan bersifat multidimensi. Hubungan antara pengungkapan tanggung jawab sosial perusahaan dan profitabilitas perusahaan telah diyakini mencerminkan pandangan bahwa reaksi social memerlukan gaya manajerial yang sama dengan gaya manajerial yang dilakukan pihak manajemen untuk membuat suatu perusahaan memperoleh keuntungan (Sembiring, 2003).

Likuiditas adalah kemampuan perusahaan dalam melunasi kewajiban jangka pendeknya. Perusahaan dengan tingkat likuiditas yang tinggi berarti perusahaan tersebut akan mengeluarkan biaya CSR yang besar sehingga kegiatan CSR yang dilakukan juga semakin banyak. Tingkat likuiditas yang tinggi menunjukkan bahwa perusahaan mampu dalam mengelola keuangannya sehingga akan menarik investor untuk melakukan investasi. Likuiditas merupakan salah satu kinerja yang sering dijadikan tolak ukur investor dalam menilai perusahaan. Ketika likuiditas yang dihasilkan rendah, perusahaan akan cenderung melakukan pengungkapan CSR makin banyak (Putri \& Christiawan, 2014).

\section{Tinjauan Literatur Dan Pengembangan Hipotesis}

Teori Legitimasi. Teori legitimasi menganjurkan perusahaan untuk meyakinkan bahwa aktivitas dan kinerjanya dapat diterima oleh masyarakat. Perusahaan menggunakan laporan tahaunan mereka untuk menggambarkan kesan tanggung jawab lingkungan, sehingga mereka diterima oleh masyarakat. Legitimasi dapat dianggap sebagai menyamakan persepsi atau 
asumsi bahwa tindakan yang dilakukan oleh suatu entitas adalah merupakan tindakan yang diinginkan, pantas ataupun sesuai dengan sistem norma, nilai, kepercayaan, dan definisi yang dikembangkan secara sosial (Suchman, 1995 dalam Kirana, 2009). Legitimasi dianggap penting bagi perusahaan dikarenakan legitimasi masyarakat kepada perusahaan menjadi faktor yang strategis bagi perkembangan perusahaan kedepan. O'Donovan (2000) berpendapat legitimasi organisasi dapat dilihat sebagai sesuatu yang diberikan masyarakat kepada perusahaan dan sesuatu yang diinginkan atau dicari perusahaan dari masyarakat. Selanjutnya untuk menjaga kepercayaan masyarakat terhadap perusahaan maka perlu juga adanya pengawasan yang baik terhadap kinerja manajemen dengan mengungkapkan informasi yang seluas-luasnya (Nuraini, 2018). Dengan demikian legitimasi memiliki manfaat untuk mendukung keberlangsungan hidup suatu perusahaan.

Legitimasi merupakan sistem pengelolaan perusahaan yang berorientasi pada keberpihakan terhadap masyarakat (society), pemerintah, individu dan kelompok masyarakat. Untuk itu, sebagai suatu sistem yang mengedepankan keberpihakan kepada masyarakat, operasi perusahaan harus kongruen dengan harapan masyarakat. Legitimasi perusahaan dapat ditingkatkan melalui tanggung jawab sosial perusahaan (CSR) (Gary dkk. dalam Nor Hadi (2011:88)). Operasi perusahaan harus sesuai dengan harapan dari masyarakat. Deegan dkk (2002) menyatakan legitimasi dapat diperoleh manakala terdapat kesesuaian antara keberadaan perusahaan tidak mengganggu atau sesuai (congruent) dengan eksistensi sistem nilai yang ada dalam masyarakat dan lingkungan. Ketika terjadi pergeseran yang menuju ketidaksesuaian, maka pada saat itu legitimasi perusahaan dapat terancam. Teori legitimasi memiliki alasan tentang hubungan ukuran perusahaan dan pengungkapan. Perusahaan yang lebih besar melakukan aktivitas yang lebih banyak sehingga memiliki pengaruh yang lebih besar terhadap masyarakat, memiliki lebih banyak pemegang saham yang punya perhatian terhadap program sosial yang dilakukan perusahaan dan laporan tahunan merupakan alat yang efisien untuk mengkomunikasikan informasi ini (Cowen et. Al., 1987 dalam Achmad (2007).

Teori Stakeholder. Teori stakeholder menyatakan bahwa perusahaan bukanlah entitas yang hanya beroperasi untuk kepentingan sendiri, tetapi juga harus memberikan manfaat bagi para stakeholder (Ghozali dan Chariri, 2007). Definisi stakeholder yang dilontarkan (Rhenald Kasali dalam Purnasiswi, 2011) adalah setiap kelompok orang baik yang berada didalam perusahaan maupun diluar perusahaan yang mempunyai peran dalam menetukan keberhasilan perusahaan. Dengan demikian, keberadaan suatu perusahaan sangat dipengaruhi oleh dukungan yang diberikan oleh stakeholder kepada perusahaan tersebut sehingga keberadaan suatu perusahaan sangat dipengaruhi oleh dukungan yang diberikan stakeholder kepada perusahaan tersebut (Fatoni dkk, 2016). Pada dasarnya tanggung jawab perusahaan tidaknya terbatas pada memaksimalkan laba demi kepentingan pemegang saham namun lebih luas lagi yakni menciptakan kesejahteraan bagi kepentingan stakeholder, yaitu semua pihak mempunyai keterkaitan terhadap perusahan. Perusahaan dalam menjalankan aktivitasnya perlu menyampaikan kegiatan usahanya secara transparan sebagai bentuk komunikasi dengan pihak shareholder maupun stakeholder. Menurut Sari (2012), perusahaan tidak hanya bertanggung jawab kepada pemilik dari segi ekonomi saja, namun bergeser lebih luas lagi sampai pada masalah sosial kemasyarakatan, sehingga muncul istilah tanggung jawab sosial (corporate social responsibility).

Tanggung jawab sosial perusahaan seharusnya melampaui tindakan memaksimalkan laba untuk kepentingan pemegang saham (shareholder), namun lebih luas lagi bahwa kesejahteraan yang diciptakan oleh perusahaan tidak terbatas kepada kepentingan pemegang saham, tetapi untuk kepentingan stakeholder, yaitu semua pihak yang mempunyai keterkaitan 
terhadap perusahaan (Untung, 2008). Mereka adalah pemasok, pelanggan, pemerintah, masyarakat lokal, investor, karyawan, kelompok politik, dan asosiasi perdagangan. Seperti halnya pemegang saham yang mempunyai hak terhadap tindakan-tindakan yang dilakukan oleh manajemen perusahaan, stakeholder juga mempunyai hak terhadap perusahaan (Waryanti, 2009). Ketika sebuah perusahaan mendapat kinerja keuangan yang baik (liquidity), perusahaan diharapkan dapat memberikan kontribusi positif melalui kegiatan sosial dan mengungkapkan laporan tahunan perusahaan. Ini berarti bahwa perusahaan juga memperdulikan kondisi masyarakat sekitar (Gagat Agus Wasito, dkk, 2016). Adanya teori stakeholder ini memberikan landasan bahwa suatu perusahaan harus mampu memberikan manfaat bagi stakeholdernya. Manfaat tersebut dapat diberikan dengan cara menerapkan program Corporate Social Responsibility (CSR). Adanya program tersebut pada perusahaan diharapkan akan meningkatkan kesejahteraan bagi karyawan, pelanggan, dan masyarakat lokal. Sehingga diharapkan terjalin hubungan yang baik antara perusahaan dengan lingkungan sekitar (Ira Robiah Adawiyah, 2013).

Menurut Effendi, Bahtiar et al (2012) menyatakan bahwa perusahaan menganggap bahwa peran para stakeholder sangat berpengaruh bagi perusahaan sehingga dapat mempengaruhi dan menjadi pertimbangan dalam mengungkapkan suatu informasi dalam laporan keuangan mereka. Stakeholder menjadi pertimbangan utama bagi perusahaan karena mereka memegang posisi yang kuat dalam perusahaan. Stakeholder pada dasarnya dapat mempengaruhi pemakaian berbagai sumber ekonomi yang digunakan dalam aktivitas perusahaan. Oleh karena itu, stakeholder theory umumnya berkaitan dengan cara-cara yang digunakan perusahaan untuk mengendalikan pengaruh stakeholder tersebut.

Corporate Social Responsibility. Menurut Bangun dkk (2012) tanggung jawab sosial perusahaan merupakan suatu komitmen bisnis yang berkelanjutan untuk memberikan kontribusi bagi pembangunan ekonomi, melalui kerjasama dengan komunitas sosial setempat maupun masyarakat umum untuk meningkatkan kualitas kehidupan dengan cara yang bermanfaat baik bagi bisnis sendiri maupun untuk pembangunan. Menurut Oktafiani dan Rizki (2015), berdirinya perusahaan di lingkungan masyarakat akan memberikan pengaruh terhadap kehidupan di sekitarnya baik secara ekonomi, sosial dan ekologi. Secara ekonomi keberadaan industri akan memberikan kesempatan kerja bagi masyarakat sehingga diharapkan dapat meningkatkan kesejahteraan hidup. Sedangkan secara sosial akan berdampak pada perubahaan perilaku sosial kemasyarakatan, dan secara ekologi akan berpengaruh terhadap pencemaran lingkungan yang diakibatkan oleh limbah pabrik, yang dapat menimbulkan polusi. Menurut Hackston dan Milne, tanggung jawab sosial perusahaan sering disebut juga sebagai corporate social resposibility atau social disclosure, corporate social reporting, social reporting merupakan proses pengkomunikasian dampak sosia dan lingkungan dari kegiatan ekonomi organisasi terhadap kelompok khusus yang berkepentingan dan terhadap masyarakat secara keseluruhan (Sembiring, 2015).

Menurut Darwin (2006) cakupan CSR sangat luas, tidak hanya terkait dengan masalah sosial semata (corporate philanthropy). Secara umum isu CSR mencakup 5 (lima) komponen pokok, yaitu:

a. Hak Asasi Manusia (HAM)

Bagaimana perusahaan menyikapi masalah HAM dan strateginya serta kebijakan yang dilakukan oleh perusahaan untuk menghindari terjadinya pelanggaran HAM dalam perusahaan.

b. Tenaga Kerja (Buruh) 
Bagaimana kondisi tenaga kerja di supply chain ataupun dipabrik, mulai dari sistem penggajian, kesejahteraan hari tua dan keselamatan kerja, peningkatan keterampilan dan profesionalisme karyawan, sampai pada pola penggunaan tenaga kerja di bawah umut.

c. Lingkungan Hidup

Bagaimana strategi dan kebijakan yang berhubungan dengan masalah lingkungan hidup. Usaha perusahaan mengatasi dampak lingkungan atas produk dan jasa mulai dari pengadaan bahan baku sampai pada masalah pembuangan limbah, serta dampak lingkungan yang diakibatkan oleh proses produksi dan distribusi produk.

d. Sosial Masyarakat

Bagaimana strategi dan kebijakan dalam bidang sosial dan pengembangan masyarakat setempat (community development), serta dampak operasi perusahaan terhadap kondisi sosial dan budaya masyarakat setempat.

e. Dampak Produk dan Jasa Terhadap Pelanggan

Apa saja yang harus dilakukan perusahaan untuk memastikan bahwa produk dan jasanya terbebas dari dampak-dampak negatif seperti mengganggu kesehatan pelanggan, mengancam keamanan dan produk yang dilarang.

Berdasarkan kelima komponen diatas maka komponen-komponen tersebut dapat dijadikan tolak ukur dalam menilai seberapa besar kesadaran perusahaan dalam memenuhi tanggung jawab sosialnya kepada stakeholdernya. Jika perusahaan hanya menjalankan salah satu komponen saja dari kelima komponen tersebut dapat dikatakan kesadaran perusahaan masih rendah. Sebaliknya, jika perusahaan memenuhi kelima komponen tersebut dapat dikatakan kesadaran perusahaan tinggi terhadap tanggung jawab sosialnya. Menurut Chariri dan Ghozali (2007), pengungkapan (disclosure) berarti tidak menutupi atau menyembunyikan. Apabila dikaitkan dengan laporan keuangan, laporan keuangan harus memberikan informasi dan penjelasan yang cukup mengenai hasil aktivitas suatu unit usaha. Sedangkan pengungkapan sosial adalah pengungkapan informasi tentang aktivitas perusahaan yang berhubungan dengan lingkungan sosial perusahaan. pengungkapan sosial dapat dilakukan melalui berbagai media antara lain laporan tahunan, laporan interim/laporan sementara, prospektus, pengumuman kepada bursa efek atau melalui media masa. Sedangkan

Global Reporting Initiative (GRI) adalah pelaporan, pengungkapan standar yang berindikator tanggung jawab sosial yang diemban oleh perusahaan untuk menciptakan/memberikan manfaat pelaporan kepada para stakeholder peerusahaan. Pedoman ini didesain untuk digunakan oleh organisasi baik ukuran, sektor, atau lokasinya juga menyediakan referensi internasional untuk semua pihak yang terlibat dengan pengungkapan pendekatan tata kelola serta kinerja dan dampak lingkungan, sosial, ekonomi dan organisasi. Pada GRI G-4 ada beberapa dampak yang ditimbulkan oleh operasi perusahaan, yaitu dampak ekonomi, dampak lingkungan, dan dampak sosial.

Ukuran Perusahaan. Ukuran perusahaan adalah skala yang digunakan dalam menentukan besar kecilnya suatu perusahaan. Secara umum perusahaan besar akan mengungkapkan informasi lebih banyak daripada perusahaan kecil. Hal ini karena perusahaan besar akan menghadapi resiko politis yang lebih besar dibanding perusahaan kecil. Secara teoritis perusahaan besar tidak akan lepas dari tekanan politis, yaitu tekanan untuk melakukan pertanggungjawaban sosial. Pengungkapan sosial yang lebih besar merupakan pengurangan biaya politis bagi perusahaan (Hasibuan, 2001). Perusahaan dengan ukuran besar memiliki akses lebih besar dan luas untuk mendapatkan sumber pendanaan dari luar, sehingga untuk memperoleh pinjaman akan menjadi lebih mudah karena dikatakan bahwa perusahaan dengan ukuran besar memiliki kesempatan lebih besar untuk memenangkan persaingan atau bertahan dalam industri (Lisa dan Jogi, 2013). 
Profitabilitas. Profitabilitas adalah kemampuan suatu perusahaan dalam memperoleh laba untuk meningkatkan nilai pemegang saham. Tingkat profitabilitas yang semakin tinggi mencerminkan kemampuan entitas dalam menghasilkan laba yang semakin tinggi, sehingga entitas mampu untuk meningkatkan tanggung jawab sosial, serta melakukan pengungkapan tanggung jawab sosialnya dalam laporan keuangan dengan lebih luas (Rindu Kurnia Putri, 2015). Profitabilitas perusahaan menujukkan perbandingan antara laba dengan aktiva atau modal yang digunakan untuk menghasilkan laba tersebut, dengan kata lain profitabilitas adalah kemampuan perusahaan untuk menghasilkan laba selama periode tertentu. Semakin tinggi tingkat profitabilitas perusahaan makan akan semakin besar pula pengungkapan informasi sosialnya (Hidayat, 2007). Dengan demikian pengukuran profitabilitas suatu perusahaan menunjukkan tingkat efektifitas manajemen secara menyeluruh dan secara tidak langsung.

Para investor jangka panjang akan sangat berkepentingan dengan analisis ini. Selain itu keuntungan (profitabilitas) sangat penting bagi perusahaan bukan saja untuk terus mempertahankan pertumbuhan bisnisnya namun juga memperkuat kondisi keuangan perusahaan. Heni Susana (2013) menyatakan bahwa profitabilitas merupakan faktor yang memberikan kebebasan dan fleksibilitas kepada manajemen untuk mengungkapkan pertanggungjawaban sosial kepada pemegang saham. Hal ini berarti semakin tinggi tingkat profitabilitas maka semakin besar pengungkapan informasi sosialnya. Selanjutnya menurut Effendi dan Khamdevi (2017) menyatakan bahwa tingkat profitabilitas yang diukur dengan ROA didalam setiap perusahaan pada kenyataannya berbeda-beda tergantung dari tindakan pengelolaan yang diambil terhadap permasalahan terkait tanggungjawab sosial yang dihadapi.

Likuiditas. Likuiditas adalah suatu kondisi yang menunjukkan kemampuan perusahaan dalam mendanai operasional perusahaan dan melunasi hutang jangka pendeknya. Rasio ini digunakan untuk memberikan gambaran mengenai pengaruh ketersediaan dana perusahaan terhadap pengungkapan CSR. Perusahaan yang secara keuangan sehat, kemungkinan akan lebih banyak mengungkapkan informasi CSR dibandingkan dengan perusahaan yang likuiditasnya rendah (Arthana, 2009). Menurut Munawir (2004) likuiditas adalah kemampuan suatu perusahaan untuk memenuhi kewajiban keuangannya yang harus dipenuhi, atau kemampuan perusahaan untuk memenuhi kewajiban keuangan saat ditagih. Perusahaan yang mampu memenuhi kewajiban keuangannya tepat pada waktunya berarti perusahaan tersebut dalam keadaan likuid dan perusahaan dikatakan mampu memenuhi kewajiban keuangan tepat pada waktunya apabila perusahaan tersebut mempunyai alat pembayaran ataupun aktiva lancar yang lebih besar dari hutang lancarnya atau hutang jangka pendek. Sebaliknya jika perusahaan tidak dapat segera memenuhi kewajiban keuangannya pada saat ditagih, berarti perusahaan tersebut dalam keadaan illikuid. Kasmir (2008) menyatakan likuiditas atau sering disebut modal kerja digunakan untuk mengukur seberapa likuidnya suatu perusahaan. likuiditas menganalisa dan menginterpretasikan posisi keuangan jangka pendek, tapi juga sangat membantu bagi manajemen untuk mengecek efisiensi modal kerja yang digunakan dalam perusahaan, juga penting bagi kreditor jangka panjang dan pemegang saham yang akhirnya atau setidak-tidaknya ingin mengetahui prospek dari deviden dan pembayaran bunga di masa yang akan datang. Dapat dipahami bahwa likuiditas menunjukkan kemampuan suatu perusahaan dalam memenuhi kewajiban jangka pendeknya atau kewajiban yang segera jatuh tempo dengan sumber jangka pendeknya. Semakin tinggi likuiditas maka semakin tinggi kemampuan perusahaan membayar hutang-hutang jangka pendeknya.

Pengaruh Ukuran Perusahaan terhadap CSRD. Menurut Sembiring (2005), secara teoritis perusahaan besar tidak akan lepas dari tekanan dan perusahaan yang lebih besar dengan aktivitas operasi dan pengaruh yang lebih besar terhadap masyarakat mungkin akan memiliki 
pemegang saham yang memperhatikan program sosial yang dibuat perusahaan sehingga pengungkapan CSR perusahaan akan semakin luas. Ukuran perusahaan juga dipertimbangkan oleh investor dalam menilai kinerja perusahaan (Purnasiwi, 2011). Beberapa penelitian, seperti Bramantya Adhi Cahya (2010), I Gusti Ayu Rika Milanda Sari dan Ni Luh Putu Sari Mimba (2015), Ervika Nila Sari (2013), dan Rina Dwi Haryani (2015) menunjukkan adanya hubungan atau pengaruh antara ukuran perusahaan dan CSR. Sedangkan menurut penelitian Oktariani (2013) dan Reka Maiyarni dkk (2014) ukuran perusahaan tidak memiliki pengaruh terhadap CSR. Berdasarkan uraian tersebut, maka dirumuskan hipotesis penelitian, yaitu:

H1: Ukuran Perusahaan berpengaruh positif signifikan terhadap CSRD.

Pengaruh Profitabilitas terhadap CSRD. Profitabilitas merupakan salah satu faktor yang membuat manajemen menjadi fleksibel untuk melaksanakan tanggung jawab sosial kepada pemegang saham. Dengan semakin tingginya tingkat profitabilitas, maka semakin besar pula pelaksanaan CSR dan pengungkapannya (Bangun dkk, 2012). Profitabilitas perusahaan menunujukkan perbandingan antara laba dengan aktiva atau modal yang digunakan untuk menghasilkan laba tersebut, dengan kata lain profitabilitas adalah kemampuan perusahaan untuk menghasilkan laba selama periode tertentu. Semakin tinggi tingkat profitabilitas perusahaan makan akan semakin besar pula pengungkapan informasi sosialnya (Hidayat, 2007). Penelitian Indun Prasetianti Rahayu (2015), Dwi Febrianti (2016), dan Ida Bagus Putri Astika mengatakan bahwa profitabilitas berpengaruh terhadap CSR. Sedangkan, Reka Maiyarni dkk (2014) dan Ira Robiah Adawiyah (2013) mengatakan bahwa profitabilitas tidak berpengaruh terhadap CSR. Berdasarkan uraian tersebut, maka dirumuskan hipotesis penelitian, yaitu:

H2: Profitabilitas berpengaruh positif signifikan terhadap CSRD.

Pengaruh Likuiditas terhadap CSRD. Perusahaan dengan likuiditas yang tinggi akan memberikan sinyal kepada perusahaan yang lain, bahwa mereka lebih baik dari perusahaan lain, dengan melakukan kegiatan yang berhubungan dengan lingkungan sosial. Sinyal tersebut dilakukan dengan cara memberikan informasi yang lebih luas tentang tanggung jawab sosial dan lingkungan yang mereka lakukan (Kamil dan Antonius, 2012 dalam Rindu Kurnia Putri, 2015). Beberapa penelitian, seperti Eka Samsiyah (2014), Alfi Khoirul Ihsan (2014), dan Syahrir dan Suhendra (2010) mengungkapkan bahwa adanya pengaruh likuiditas terhadap CSR. Sedangkan menurut Dwi Febrianti (2016) dan Indun Prasetianti Rahayu (2015) mengungkapkan bahwa tidak ada hubungan atau pengaruh antara likuiditas terhadap CSR. Berdasarkan uraian tersebut, maka dirumuskan hipotesis penelitian, yaitu:

H3: Likuiditas berpengaruh positif signifikan terhadap CSRD.

\section{Metode Penelitian}

Teknik pengumpulan data yang dilakukan penelitian ini adalah dengan mengumpulkan data empiris berupa sumber data yang dibuat perusahaan yang berupa laporan tahuanan dan laporan CSR perusahaan. Data dalam penelitian ini adalah laporan tahunan perusahaan pertambangan yang sudah terdaftar di Bursa Efek Indonesia periode 2014-2016 yang diperoleh melalui website.

Sumber data penelitian yang digunakan penulis adalah data sekunder. Data sekunder adalah sumber data penelitian yang diperoleh peneliti secara tidak langsung melalui media perantara (diperoleh dan dicatat oleh pihak lain). Data sekunder umumnya berupa bukti, 
catatat atau laporan historis yang telah tersusun dalam arsip yang dipublikasikan dan yang tidak dipublikasikan (Indriantoro dan Supomo, 2002). Data sekunder dari penelitian ini diambil dari:

1. Laporan tahuanan perusahaan yang diperoleh dari Bursa Efek Indonesia (BEI).

2. Jurnal-jurnal, skripsi dan bahan dari internet yang berhubungan dengan pengungkapan Corporate Social Responsibility (CSR).

Penyeleksian sampel penelitian menggunakan teknik purposive sampling (teknik pemilihan sampel bertujuan). Tujuan penggunaan teknik purposive sampling adalah agar diperoleh sampel yang mampu mewakili populasi sesuai dengan kriteria yang ditentukan. Beberapa kriteria yang diambil dalam menentukan perusahaan-perusahaan yang akan dipilih sebagai sampel adalah sebagai berikut:

1. Perusahaan yang terdaftar di Bursa Efek Indonesia yang masuk ke dalam sektor pertambangan periode 2014-2016.

2. Perusahaan tersebut menerbitkan annual report periode 2014-2016.

3. Perusahaan menyediakan informasi mengenai pelaksanaan CSR.

4. Menyajikan data perusahaan yang lengkap sesuai dengan variabel yang diteliti.

Ukuran Perusahaan. Ukuran perusahaan bisa didasari pada jumlah aktiva (aktiva tetap, tidak berwujud, dan lain-lain), jumlah tenaga kerja, volume penjualan dan kapitalisasi pasar (Nur Cahyonowati, 2003). Ukuran perusahaan adalah suatu skala dimana dapat diklasifikasikan besar kecilnya perusahaan. Pada penelitian ini ukuran perusahaan dapat dirumuskan sebagai berikut:

$$
\text { Firm Size }=\log n \text { Total Aset }
$$

Profitabilitas. Profitabilitas diartikan sebagai kemampuan perusahaan untuk menghasilkan laba atau profit dalam upaya meningkatkan nilai pemegang saham. Terdapat beberapa ukuran untuk menentukan profitabilitas perusahaan, yaitu return of equity, return on assets, earning per share, net profit margin, dan operating ratio (Bramantya Adhi Cahya, 2010).

Penelitian ini menggunakan Return on Asset (ROA) untuk menentukan profitabilitas perusahaan. ROA adalah perbandingan antara laba bersih setelah pajak dengan aktiva untuk mengukur tingkat pengembalian investasi total (Stoner dan Sirait, 1994). Pengukuran profitabilitas dapat dirumuskan sebagai berikut:

$$
R O A=\frac{\text { Laba Bersih Setelah Pajak }}{\text { Total Aktiva }}
$$

Likuiditas. Likuiditas adalah kemampuan suatu perusahaan untuk memenuhi kewajiban keuangannya yang harus dipenuhi, atau kemampuan perusahaan untuk memenuhi kewajiban keuangan saat ditagih. Perusahaan yang mampu memenuhi kewajiban keuangan tepat pada waktunya berarti perusahaan tersebut dalam keadaan likuid, dan perusahaan dikatakan mampu memenuhi kewajiban keuangan tepat pada waktunya apabila perusahaan tersebut mempunyai alat pembayaran ataupu aktiva lancar yang lebih besar dari hutang lancarnya atau hutang jangka pendek. Dalam penelitian ini, likuiditas diukur dengan current ratio yang dapat dirumuskan sebagai berikut:

$$
\text { Current Ratio }=\frac{\text { Current Asset }}{\text { Current Liabilities }}
$$

\section{Hasil Penelitian dan Pembahasan}

Analisis Statistik Deskriptif. Berdasarkan hasil analisis statistik deskriptif, maka dalam Tabel 4.2.1 berikut akan ditampilkan karakteristik sampel yang digunakan didalam penelitian 
ini meliputi: jumlah sampel $(\mathrm{N})$, rata-rata sampel (mean), dan standar deviasi untuk masingmasing variabel.

Tabel 1. Deskripsi Variabel Penelitian Descriptive Statistics

\begin{tabular}{|l|r|r|r|r|r|}
\hline & N & Minimum & Maximum & Mean & $\begin{array}{c}\text { Std. } \\
\text { Deviation }\end{array}$ \\
\hline $\begin{array}{l}\text { Ukuran } \\
\text { Perusahaan }\end{array}$ & 38 & 10.33 & 12.31 & 11.4759 & .43845 \\
\hline Profitabilitas & 38 & -.98 & .07 & -.1517 & .32105 \\
\hline Likuiditas & 38 & .72 & 2.71 & 1.4026 & .41934 \\
\hline CSR & 38 & 15.38 & 23.52 & 18.7449 & 3.57572 \\
\hline $\begin{array}{l}\text { Valid N } \\
\text { (listwise) }\end{array}$ & 38 & & & & \\
\hline
\end{tabular}

Sumber: Data sekunder yang diolah dengan SPSS versi 24.0 (2018)

Tabel 1 menunjukkan statistik deskriptif masing-masing variabel penelitian. Berdasarkan tabel 1, hasil analisis dengan menggunakan statistik deskriptif terhadap ukuran perusahaan (size) yang dihitung dengan cara menghitung log dari total asset menunjukkan hasil analisis deskriptif dengan nilai minimum sebesar 10,33, nilai maksimum sebesar 12,31, nilai rata-rata sebesar 11,4759 dan nilai standar deviasi sebesar 0,43845 . Profitabilitas yang dihitung dengan menggunakan rasio Return on Asset (ROA) dengan cara membagi jumlah laba bersih setelah pajak dengan total asset menunjukkan nilai minimum sebesar -0,98, nilai maksimum sebesar 0,07 , nilai rata-rata sebesar $-0,1517$ dan nilai standar deviasinya sebesar 0,32105. Hasil analisis dengan menggunakan statistik deskriptif terhadap likuiditas yang dihitung menggunakan Current Ratio dengan cara membagi asset lancar dengan hutang lancar menunjukkan hasil analisis deskriptif dengan nilai minimum sebesar 0,72 , nilai maksimum sebesar 2,71, nilai rata-rata sebesar 1,4026 dan nilai standar deviasi sebesar 0,41934. Selain itu pengungkapan Corporate Social Responsibility (CSRD) dengan melihat jumlah item pengungkapan yang dilakukan perusahaan, menunjukkan nilai minimum sebesar 15,38 , nilai maksimum sebesar 23,52 , nilai rata-rata sebesar 18,7449 dan nilai standar deviasi sebesar 3,57572.

\section{Uji Normalitas}

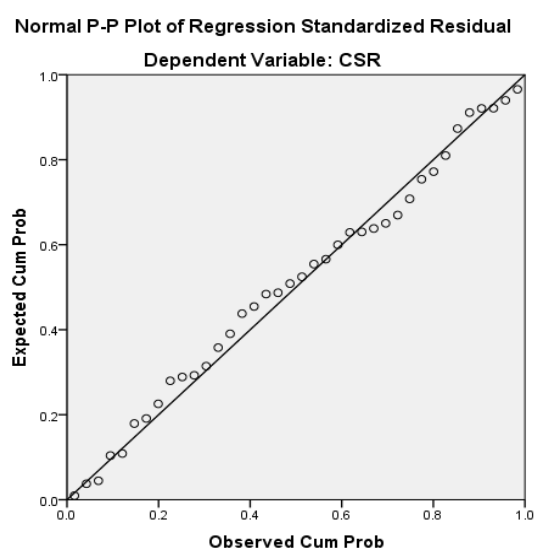

Gambar 1. Hasil Uji Normalitas

Sumber: Data sekunder yang diolah dengan SPSS versi 24.0 (2018) 
Grafik P-P Plot diatas menunjukkan bahwa pola distribusi data mendekati atau menyentuh garis diagonal yang berarti nilai residual berdistribusi normal. Hasil uji normalitas bisa juga dilihat dengan menggunakan uji Kolmogorov-Smirnov untuk meyakinkan bahwa data telah terdistribusi secara normal. Berikut merupakan tabel hasil uji KolmogorovSmirnov.

Tabel 2. One-Sample Kolmogorov-Smirnov

Test

\begin{tabular}{ccc} 
& & $\begin{array}{c}\text { Unstandardi } \\
\text { zed Residual }\end{array}$ \\
\hline \multicolumn{1}{c}{$\mathrm{N}$} & & 38 \\
\hline Normal Parameters & Mean & .0000000 \\
\cline { 2 - 3 } & $\begin{array}{c}\text { Std. } \\
\text { Deviation }\end{array}$ & 2.37170768 \\
\hline Most Extreme & Absolute & .067 \\
\cline { 2 - 3 } Differences & Positive & .060 \\
\cline { 2 - 3 } & Negative & -.067 \\
\hline \multicolumn{2}{c}{ Test Statistic } & .067 \\
\hline \multicolumn{2}{c}{ Asymp. Sig. (2-tailed) } & $.200^{\mathrm{c}, \mathrm{d}}$ \\
\hline
\end{tabular}

a. Test distribution is Normal.

b. Calculated from data.

c. Lilliefors Significance Correction.

d. This is a lower bound of the true significance.

Sumber: Data sekunder yang diolah dengan SPSS versi 24.0 (2018)

Hasil uji normalitas dengan menggunakan uji One-Sample Kolmogorov-Smirnov menyatakan bahwa nilai signifikansi sebesar 0,200 lebih besar dari 0,05 sehingga dapat disimpulkan bahwa data yang diuji berdistribusi normal atau memenuhi asumsi klasik.

Uji Multikolinearitas. Hasil uji multikolinearitas dapat dilihat pada tabel 3 dibawah ini.

Tabel 3. Hasil Uji Multikolinearitas

\begin{tabular}{|c|c|c|c|}
\hline \multicolumn{4}{|c|}{ Coefficients $^{\mathbf{a}}$} \\
\hline \multirow[b]{2}{*}{ Model } & & \multicolumn{2}{|c|}{$\begin{array}{c}\text { Collinearity } \\
\text { Statistics }\end{array}$} \\
\hline & & Tolerance & VIF \\
\hline \multirow[t]{4}{*}{1} & (Constanta) & & \\
\hline & $\begin{array}{l}\text { Ukuran } \\
\text { Perusahaan }\end{array}$ & .754 & 1.327 \\
\hline & Profitabilitas & .752 & 1.330 \\
\hline & Likuiditas & .950 & 1.052 \\
\hline
\end{tabular}

a. Variabel:CSR

Sumber: Data sekunder yang diolah dengan SPSS versi 24.0 (2018)

Dari tabel 4.3.2 diatas dapat dilihat bahwa semua variabel independen memiliki nilai Tolerance yang berada di bawah 1 dan nilai VIF yang berada jauh di bawah angka 10 yang berarti dalam model ini tidak terdapat masalah multikolinearitas. 
Uji Heteroskedastisitas. Berikut merupakan hasil uji heteroskedastisitas yang dapat dilihat pada gambar 2 dibawah ini.

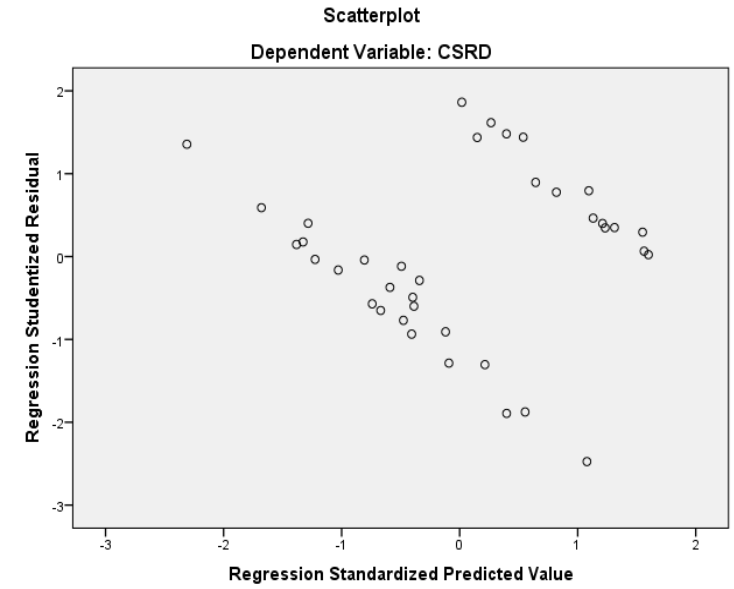

Gambar 2. Hasil Uji Heteroskedastistias

Sumber: Data sekunder yang diolah dengan SPSS versi 24.0 (2018)

Gambar 2 diatas terlihat bahwa dari grafik scatterplots yang ada penyebaran titik-titik data tidak membentuk pola dan menyebar secara acak. Titik-titik data tersebar di atas dan di bawah atau di sekitar angka 0 pada sumbu $Y$ dan tidak mengumpul hanya di atas atau di bawah saja. Dengan demikian dapat disimpulkan bahwa tidak terjadi masalah heteroskedastisitas sehingga model regresi yang baik dan ideal dapat terpenuhi.

Tabel 4 merupakan hasil uji heteroskedastisitas dengan menggunakan uji Glejser. Uji Glejser dilakukan agar terdapat keyakinan terhadap hasil analisis regresi yang dilakukan. Berikut merupakan hasil uji Glejser yang dapat dilihat pada tabel 4 dibawah ini.

Tabel 4. Hasil Uji Glejser

Coefficients ${ }^{\mathbf{a}}$

\begin{tabular}{|c|c|c|c|c|c|c|}
\hline Model & & $\begin{array}{r}\text { Unstan } \\
\text { Coef } \\
\text { B }\end{array}$ & $\begin{array}{l}\text { ardized } \\
\text { cients } \\
\text { Std. } \\
\text { Error }\end{array}$ & $\begin{array}{c}\text { Standardized } \\
\text { Coefficients } \\
\text { Beta }\end{array}$ & $\mathrm{t}$ & Sig. \\
\hline \multirow[t]{4}{*}{1} & (Constant) & 9.090 & 7.573 & & 1.200 & .238 \\
\hline & $\begin{array}{l}\text { Ukuran } \\
\text { Perusahaan }\end{array}$ & -.592 & .658 & -.175 & -.900 & .374 \\
\hline & Profitabilitas & .543 & .899 & .117 & .603 & .550 \\
\hline & Likuiditas & -.275 & .612 & -.078 & $-.45-$ & .656 \\
\hline
\end{tabular}

a.Dependent Variable: RES2

Sumber: Data sekunder yang diolah dengan SPSS versi 24.0 (2018)

Dari tabel 4 diatas dapat dilihat bahwa nilai signifikansi ketiga variabel independen bernilai >0,05. Dengan demikian dapat disimpulkan bahwa tidak terjadi masalah heteroskedastisitas pada model regresi. 
Uji Autokorelasi. Berikut merupakan hasil uji korelasi yang dapat dilihat pada tabel 5 di bawah ini.

Tabel 5. Hasil Uji Autokorelasi

\begin{tabular}{|c|c|c|c|c|c|}
\hline & & \multicolumn{4}{|c|}{ Model Summary ${ }^{\text {b }}$} \\
\hline Model & $\mathrm{R}$ & $\begin{array}{c}\mathrm{R} \\
\text { Square }\end{array}$ & $\begin{array}{c}\text { Adjusted } \\
\text { R } \\
\text { Square } \\
\end{array}$ & $\begin{array}{c}\text { Std. } \\
\text { Error of } \\
\text { the } \\
\text { Estimate }\end{array}$ & $\begin{array}{l}\text { Durbin- } \\
\text { Watson }\end{array}$ \\
\hline 1 & $.748^{a}$ & .560 & .521 & 2.474 & 1.226 \\
\hline $\mathrm{a}$ & $\begin{array}{l}\text { Predictors: } \\
\text { Dependent }\end{array}$ & \multicolumn{4}{|c|}{$\begin{array}{l}\text { (Constant), Likuiditas, Ukuran } \\
\text { Perusahaan, Profitabilitas }\end{array}$} \\
\hline
\end{tabular}

Sumber: Data sekunder yang diolah dengan SPSS versi 24.0 (2018)

Dilihat dari tabel 5 dapat diketahui bahwa nilai Durbin-Watson sebesar 1,226. Angka D-W berada diantara -2 sampai +2 menunjukkan bahwa model regresi yang akan digunakan tidak terdapat masalah autokorelasi.

Uji Signifikansi Simultan (F). Pada tabel 6 pengujian secara simultan (uji F), dimaksudkan untuk mengetahui apakah variabel ukuran perusahaan, profitabilitas, dan likuiditas secara bersama-sama memiliki pengaruh terhadap CSRD.

Tabel 6. Hasil Uji F

ANOVA $^{\mathrm{a}}$

\begin{tabular}{|c|c|c|c|c|c|c|}
\hline Model & & $\begin{array}{c}\text { Sum of } \\
\text { Squares }\end{array}$ & Df & $\begin{array}{c}\text { Mean } \\
\text { Square }\end{array}$ & F & Sig. \\
\hline 1 & Regression & 264.949 & 3 & 88.316 & 14.428 & $.000^{\mathbf{b}}$ \\
\hline & Residual & 208.125 & 34 & 6.121 & & \\
\hline & Total & 473.074 & 37 & & & \\
\hline
\end{tabular}

Sumber: Data sekunder yang diolah dengan SPSS versi 24.0 (2018)

Berdasarkan tabel 6, didapatkan nilai $\mathrm{F}$ statistik sebesar 3,27. Karena nilai F hitung bernilai 14,428 lebih besar dari nilai $\mathrm{F}$ statistik 3,27 dan nilai signifikansi 0,000 lebih kecil dari 0,05, maka dapat diketahui bahwa variabel independen yang terdiri dari ukuran perusahaan, profitabilitas, dan likuiditas berpengaruh secara simultan terhadap CSRD.

Koefisien Determinasi (Adjusted R-Square). Hasil perhitungan koefisien determinasi (Adjusted R-Square) dapat dilihat pada tabel 7 di bawah ini.

Tabel 7. Koefisien Determinasi

Model Summary ${ }^{b}$

\begin{tabular}{|l|c|r|r|r|}
\hline Model & $\mathrm{R}$ & R Square & $\begin{array}{c}\text { Adjusted R } \\
\text { Square }\end{array}$ & $\begin{array}{l}\text { Std. Error of } \\
\text { the Estimate }\end{array}$ \\
\hline 1 & $.748^{a}$ & .560 & .521 & 2.474 \\
\hline
\end{tabular}


Sumber: Data sekunder yang diolah dengan SPSS versi 24.0 (2018)

Tabel 7 menunjukkan bahwa nilai koefisien determinasi (Adjusted R-Square) diperoleh sebesar 0,521 atau 52,1\%. Hal ini dapat disimpulkan bahwa besar pengaruh variabel independen yaitu ukuran perusahaan, profitabilitas, dan likuiditas terhadap variabel dependen CSRD yang dapat diterangkan oleh model persamaan ini sebesar $52,1 \%$. Sedangkan sisanya sebesar $47,9 \%$ dijelaskan oleh variabel lain yang tidak masuk dalam model penelitian ini.

Analisis Regresi Berganda. Berikut merupakan hasil analisis regresi berganda yang dapat dilihat dari tabel 8 di bawah ini.

Tabel 8. Hasil Analisis Regresi Berganda

\begin{tabular}{|c|c|c|c|c|c|c|c|c|}
\hline Model & & \multicolumn{2}{|c|}{$\begin{array}{l}\text { Unstandardized } \\
\text { Coefficients }\end{array}$} & $\begin{array}{c}\text { Standardized } \\
\text { Coefficients } \\
\text { Beta } \\
\end{array}$ & $\mathrm{t}$ & Sig. & \multicolumn{2}{|c|}{$\begin{array}{l}\text { Collinearity } \\
\text { Statistics }\end{array}$} \\
\hline \multirow[t]{4}{*}{1} & (Constanta) & 74.157 & 12.304 & & 6.027 & .000 & & \\
\hline & $\begin{array}{l}\text { Ukuran } \\
\text { Perusahaan }\end{array}$ & -4.300 & 1.069 & -.527 & $\begin{array}{r}- \\
4.023\end{array}$ & .000 & .754 & 1.327 \\
\hline & Profitabilitas & 1.104 & 1.461 & .099 & .755 & .455 & .752 & 1.330 \\
\hline & Likuiditas & -4.208 & .995 & -.494 & $4.230^{-}$ & .000 & .950 & 1.052 \\
\hline
\end{tabular}

a. Dependent Var: CSRD

Sumber: Data sekunder yang diolah dengan SPSS versi 24.0 (2018)

Dengan melihat tabel 8 di atas, maka persamaan regresi linear bergandanya adalah sebagai berikut:

CSRD = 74,157 - 4,300X1 + 1,104X2 - 4,208X3

Interpretasi dari model regresi di atas adalah sebagai berikut:

1. Nilai konstanta sebesar 74,157 berarti jika semua variabel ukuran perusahaan, profitabilitas, dan likuiditas nilainya 0, maka nilai variabel CSRD adalah sebesar 74,157.

2. Ukuran perusahaan (X1) terhadap CSRD (Y)

Nilai koefisien ukuran perusahaan (X1) sebesar -4,300 artinya jika variabel independen lain nilainya tetap dan ukuran perusahaan mengalami kenaikan sebesar 1\%, maka CSRD akan mengalami penurunan sebesar 4,300.

3. Profitabilitas (X2) terhadap CSRD (Y)

Nilai koefisien profitabilitas (X2) sebesar 1,104 artinya jika variabel independen lain nilainya tetap dan profitabilitas mengalami kenaikan sebesar 1\%, maka CSRD akan mengalami peningkatan sebesar 1,104.

4. Likuiditas (X3) terhadap CSRD (Y)

Nilai koefisien likuiditas (X3) sebesar -4,208 artinya jika variabel independen lain nilainya tetap dan likuiditas mengalami kenaikan sebesar 1\%, maka CSRD akan mengalami penurunan sebesar 4,208.

Uji Signifikansi Parameter Individual ( $\boldsymbol{t}$ test). Pengujian ini bertujuan untuk mengetahui pengaruh variabel bebas (ukuran perusahaan, profitabilitas, dan likuiditas) berpengaruh signifikan atau tidak terhadap CSRD. Tabel 9 merupakan hasil pengujian uji signifikansi parameter individual (t-test). 
Tabel 9. Hasil Uji T

\begin{tabular}{|c|c|c|c|c|c|c|}
\hline Model & & $\begin{array}{r}\text { Unstan } \\
\text { Coeff } \\
\text { B } \\
\end{array}$ & $\begin{array}{l}\text { ardized } \\
\text { cients } \\
\text { Std. } \\
\text { Error }\end{array}$ & $\begin{array}{c}\text { Standardized } \\
\text { Coefficients } \\
\text { Beta }\end{array}$ & $\mathrm{t}$ & Sig. \\
\hline \multirow[t]{4}{*}{1} & (Constanta) & 74.157 & 12.304 & & 6.027 & .000 \\
\hline & $\begin{array}{l}\text { Ukuran } \\
\text { Perusahaan }\end{array}$ & -4.300 & 1.069 & -.527 & 4.023 & .000 \\
\hline & Profitabilitas & 1.104 & 1.461 & .099 & .755 & .455 \\
\hline & Likuiditas & -4.208 & .995 & -.494 & $4.230^{\circ}$ & .000 \\
\hline
\end{tabular}

a. CSRD

Sumber: Data sekunder yang diolah dengan SPSS versi 24.0 (2018)

Berdasarkan tabel 9 di atas dapat disimpulkan bahwa:

1. Pengaruh ukuran perusahaan terhadap CSRD

Berdasarkan tabel di atas diperoleh nilai signifikansi sebesar $0,000<0,05$ tetapi karena nilai t nya sebesar -4,023, maka disimpulkan H1 ditolak karena ukuran perusahaan berpengaruh negatif signifikan terhadap CSRD.

2. Pengaruh profitabilitas terhadap CSRD

Berdasarkan tabel di atas diperoleh nilai signifikansi sebesar 0,455 >0,05, maka disimpulkan $\mathrm{H} 2$ ditolak karena profitabilitas tidak berpengaruh terhadap CSRD.

3. Pengaruh likuiditas terhadap CSRD

Berdasarkan tabel di atas diperoleh nilai signifikansi sebesar $0,000<0,05$ tetapi karena nilai $\mathrm{t}$ nya sebesar $-4,230$, maka disimpulkan $\mathrm{H} 3$ ditolak karena likuiditas berpengaruh negatif signifikan terhadap CSRD.

Pengaruh Ukuran Perusahaan terhadap CSRD. Hipotesis pertama yang diajukan menyatakan bahwa diduga ukuran perusahaan bepengaruh positif signifikan terhadap CSR. Berdasarkan hasil penelitian ini, diperoleh nilai regresi koefisien ukuran perusahaan sebesar 4,300 dengan nilai t hitung sebesar $-4,023$ dan nilai signifikansi 0,000 . Hasil tersebut menunjukkan bahwa tingkat signifikansi $<0,05$ yang berarti berpengaruh negatif signifikan terhadap CSRD. Hal ini berarti hipotesis yang diajukan dalam penelitian ini ditolak. Hasil penelitian ini sejalan dengan hasil penelitian Oktariani (2013) dan Reka Maiyarni dkk (2014) ukuran perusahaan tidak berpengaruh terhadap CSRD.

Secara umum, semakin besar ukuran perusahaan maka tingkat pengungkapan informasi CSR yang dilakukan oleh perusahaan akan selalu lebih luas. Pengaruh ukuran perusahaan yang negatif menunjukkan bahwa realisasi pengungkapan CSR pada perusahaan relatif rendah. Dan tidak semua perusahaan menggunakan pedoman pengungkapan CSR yang terbaru (GRI G-4) dimana indikator pengungkapan CSR dalam pedoman ini lebih luas. Dalam teori legitimasi dikatakan bahwa perusahaan akan berusaha menaati dan menjalankan peraturan dan norma-norma yang ada dalam masyarakat agar keberadaan perusahaan dapat diterima di tengah masyarakat. Dan dengan adanya Undang-Undang No. 40 Tahun 2007, perusahaan publik wajib menerapkan kegiatan CSR. Disini dapat disimpulkan bahwa kebanyakan perusahaan menerapkan kegiatan CSR tidak lagi bersifat sukarela. Dan pengungkapan CSR diketahui memiliki pengaruh sangat penting bagi perusahaan publik guna mengangkat citra perusahaan dan meningkatkan daya jual ditengah ketatnya persaingan. Oleh 
karena itu, besar kecilnya perusahaan dan seberapa besar asset yang dimiliki perusahaan tidak berpengaruh terhadap pengungkapan CSR perusahaan tersebut.

Pengaruh Profitabilitas terhadap CSRD. Hipotesis kedua yang diajukan menyatakan bahwa diduga profitabilitas berpengaruh positif signifikan terhadap CSRD. Berdasarkan hasil penelitian ini, diperoleh nilai regresi koefisien profitabilitas sebesar 1,104 dengan nilai $\mathrm{t}$ hitung 0,755 dan signifikansi 0,455. Hasil tersebut menunjukkan bahwa tingkat signifikansi > 0,05 yang berarti tidak berpengaruh terhadap CSRD. Hal ini berarti hipotesis yang diajukan dalam penelitian ini ditolak. Hasil penelitian ini sejalan dengan hasil penelitian Reka Maiyarni dkk (2014) dan Ira Robiah Adawiyah (2013) mengatakan bahwa profitabilitas tidak berpengaruh terhadap CSRD.

Dalam teori stakeholder dikatakan bahwa tanggung jawab sosial perusahaan seharusnya melampaui tindakan memaksimalkan laba untuk kepentingan pemegang saham (shareholder), namun lebih luas lagi bahwa kesejahteraan yang diciptakan perusahaan tidak terbatas hanya kepada kepentingan pemegang saham saja, tetapi semua pihak yang mempunyai keterkaitan terhadap perusahaan (Untung, 2008). Tetapi pada realisasinya, perusahaan yang memiliki profitabilitas yang tinggi tidak selalu bergantung pada pengungkapan CSRnya karena perusahaan akan lebih berorientasi pada laba semata dan merasa tidak perlu melaporkan hal-hal yang mengganggu infornasi tentang suksesnya keuangan perusahaan tersebut. Sedangkan jika profitabilitas perusahaan rendah, maka perusahaan cenderung akan melakukan pengungkapan CSR yang lebih luas.

Pengaruh Likuiditas terhadap CSRD. Hipotesis kedua yang diajukan menyatakan bahwa diduga profitabilitas berpengaruh positif signifikan terhadap CSRD. Berdasarkan hasil penelitian ini, diperoleh nilai regresi koefisien profitabilitas sebesar -4,208 dengan nilai $t$ hitung $-4,230$ dan signifikansi 0,000. Hasil tersebut menunjukkan bahwa tingkat signifikansi $<0,05$ yang berarti berpengaruh negatif terhadap CSRD. Hal ini berarti hipotesis yang diajukan dalam penelitian ini ditolak. Hasil penelitian ini sejalan dengan hasil penelitian Dwi Febrianti (2016) dan Indun Prasetianti Rahayu (2015) mengungkapkan bahwa tidak ada hubungan atau pengaruh antara likuiditas terhadap CSRD.

Teori stakeholder menyatakan bahwa perusahaan yang memiliki tingkat likuiditas yang tinggi merupakan gambaran keberhasilan perusahaan dalam membayar kewajibankewajiban jangka pendeknya tepat waktu. Hal ini tentu saja akan menciptakan image yang positif dan kuat yang melekat pada perusahaan sehingga memungkinkan pihak stakehoders untuk selalu ada dan mendukung perusahaan tersebut (Suryono dan Prastiwi, 2011). Perusahaan yang memiliki kinerja keuangan yang baik (liquid) berarti dapat memenuhi kegiatan operasionalnya, sehingga peluang untuk melaksanakan kegiatan CSR juga semakin besar. Pengaruh likuiditas yang negatif menunjukkan bahwa pada realisasinya, perusahaan cenderung tidak melakukan pengungkapan sosial karena memiliki kinerja finansial yang baik dan memiliki anggapan bahwa pengungkapan CSR tidaklah memiliki pengaruh terhadap investor. Sementara, perusahaan yang memiliki likuiditas yang rendah akan melakukan pengungkapan CSR untuk menarik minat para investor.

\section{Simpulan dan Saran}

Simpulan. Dari hasil analisis data, uji asumsi klasik, pengujian hipotesis, serta interpretasi hasil, maka dapat ditarik kesimpulan dari penelitian ini, sebagai berikut:

1. Ukuran perusahaan berpengaruh negatif signifikan terhadap CSRD. Hasil penelitian ini menunjukkan bahwa realisasi praktik pengungkapan CSR rendah dan besar atau kecilnya perusahaan tidak berpengaruh terhadap pengungkapan CSRnya. 
2. Profitabilitas tidak berpengaruh terhadap CSRD. Hasil penelitian ini menunjukkan bahwa perusahaan yang memiliki tingkat profitabilitas yang tinggi belum tentu mengungkapkan informasi CSR secara luas.

3. Likuiditas berpengaruh negatif signifikan terhadap CSR. Hasil penelitian ini menunjukkan bahwa semakin besar likuiditas suatu perusahaan maka pengungkapan informasi CSRnya akan semakin rendah.

Keterbatasan Penelitian. Penelitian ini memiliki keterbatasan yaitu tidak semua perusahaan sampel menggunakan pedoman pengungkapan CSR yang terbaru yaitu GRI G-4.

\section{Saran}

1. Bagi perusahaan, diharapkan dapat lebih lengkap dalam mengungkapkan informasi tentang kegiatan-kegiatan perusahaan yang berhubungan dengan tanggung jawab sosial perusahaan (Corporate Social Resposibility) dengan menggunakan pedoman pengungkapan CSR yang terbaru.

2. Bagi penelitian selanjutnya diharapkan menggunakan sampel penelitian perusahaan yang melakukan kegiatan sosial yang lebih luas sesuai dengan indikator-indikator pengungkapan CSR yang ada pada pedoman GRI G-4.

3. Bagi investor, dalam membuat keputusan sebaiknya para investor memperhatikan ukuran perusahaan. Perusahaan yang memiliki ukuran perusahaan besar cenderung akan melakukan pengungkapan CSR dalam tingkat yang tinggi, karena aktivitas sosial erat kaitannya dengan keberlanjutan jangka panjang perusahaan.

\section{DAFTAR PUSTAKA}

Adawiyah, Ira. (2013). Pengaruh Tipe Industri, Ukuran Perusahaan, Profitabilitas, dan Leverage Terhadap Pengungkapan Corporate Social Responsibility (Studi Empiris Pada Perusahaan Go Public yang Terdaftar di Jakarta Islamic Index Periode 20082012). Skripsi. Universitas Islam Negeri Syarif Hidayatullah, Jakarta.

Ais, Widya \& Sophiah, Siti. (2016). Pengungkapan Corporate Social Responsibility Berdasarkan Global Reporting Initiative (GRI-G4) Pada Perbankan Indonesia. Jurnal INTEKNA. Politeknik Negeri Banjarmasin.

Anggraini, Rafika \& Jogi, Yulius. (2014). Pengaruh Profitabilitas, Likuiditas, dan Leverage Terhadap Pengungkapan Corporate Social Responsibility (Studi Pada PerusahaanPerusahaan yang Mendapat Penghargaan ISRA dan Listed (Go-Public) di Bursa Efek Indonesia (BEI) 2010-2012). Business Accounting Review. Universitas Kristen Petra.

Agus, Gagat, Eliada Herwiyanti, \& Widya Hayu. (2016). Pengaruh Corporate Governance, Profitabilitias, Likuiditas, dan Solvabilitas terhadap Corporate Social Responsibility Disclosure. Jurnal Bisnis dan Akuntansi. Universitas Jendral Soedirman.

Bastiandi, Benny. (2016). Limbah Pabrik Semen Diduga Cemari Mata Air di Sukabumi. http://m.metrotvnews.com/jabar/peristiwa/lKYm6jJK-limbah-pabrik-semen-didugacemari-mata-air-di-sukabumi.

Cahya, Bramantya Adhi. (2010). Analisis Pengaruh Kinerja Keuangan Terhadap Tanggung Jawab Sosial Perusahaan (Corporate Social Responsibility) (Studi Pada Bank di Indonesia Periode Tahun 2007-2008). Skripsi. Universitas Diponegoro, Semarang.

Effendi, Bahtiar., Uzliawati, Lia \& Yulianto, Agus S. (2012). Pengaruh Dewan Komisaris terhadap Environmental Disclosure pada Perusahaan Manufaktur yang Listing di BEI Tahun 2008-2011. Jurnal Riset Akuntansi Indonesia. Serang: Universitas Sultan Ageng Tirtayasa. 
Effendi, Bahtiar. (2017). Ukuran Perusahaan, Jumlah Rapat Dewan Komisaris dan Environmental Disclosure di Indonesia. At Negotium Procuratio: Jurnal Bisnis dan Manajemen, 3(2), 13-25.

Effendi, Bahtiar \& Khamdevi, Muhammar. (2017). Tingkat Efisiensi Energi Bangunan Hijau dan Profitabilitas Manufaktur. MARKA (Media Arsitektur dan Kota): Jurnal Ilmiah Penelitian, 1(1), 19-24 .

Effendi, Bahtiar. (2018). Dapatkah Dewan Komisaris Melejitkan Praktik Environmental Disclosure di Indonesia?. Konferensi Akuntansi Banten I, Serang. IAI KaPd.

Effendi, Bahtiar. (2018). Ukuran Perusahaan, Dewan Komisaris dan Environmental Disclosure. Jurnal Riset Akuntansi Tirtayasa, 3(1), 1-19.

Effendi, Bahtiar. (2017). Ukuran Perusahaan, Jumlah Rapat Dewan Komisaris dan Environmental Disclosure di Indonesia. At Negotium Procuratio: Jurnal Bisnis dan Manajemen, 3(2), 13-25.

Effendi, Bahtiar. (2019). Pengaruh Implementasi Program Corporate Social Responsibility Terhadap Kepuasan Masyarakat (Studi Kasus pada PT. Krakatau Steel, Tbk. di Kota Cilegon). Dalam Proceeding FRIMA (Festival Riset Ilmiah Manajemen dan Akuntansi). Bandung. STIE STEMBI Bandung.

Febrianti, Dwi. (2016). Pengaruh Kinerja Keuangan Terhadap Corporate Social Responsibility Expenditure dan Corporate Social Responsibility Disclosure (Studi Empiris Pada Perusahaan Sektor Pertambangan yang Terdaftar di Bursa Efek Indonesia Tahun 2011-2015). Universitas Muhammadiyah Yogyakarta, Yogyakarta.

Haryani, Rina Dwi. (2015). Analisis Pengaruh Kinerja Keuangan Terhadap Tanggung Jawab Sosial Perusahaan Perbankan yang Terdaftar di Bursa Efek Indonesia. Artikel Publikasi Ilmiah. Universitas Muhammadiyah Surakarta.

Rika, I Gusti Ayu \& Harta, Ni Luh Putu Sri. (2015). Pengaruh Manajemen Laba, Kinerja Keuangan, Ukuran Perusahaan dan Pertumbuhan Perusahaan Pada Pengungkapan Corporate Social Responsibility. E-jurnal Akuntansi Universitas Udayana. Universitas Udayana, Bali.

Ihsan, Alifi Khoirul. (2014). Pengaruh Ukuran Perusahaan, Leverage, Likuiditas, dan Profitabilitas Terhadap Luas Pengungkapan Sosial Dalam Laporan Tahunan Perusahaan (Studi Empiris Pada Perusahaan Manufaktur yang Terdaftar di BEI). Artikel Ilmiah Mahasiswa. Universitas Jember.

Lind, Douglas A., William G. Marchal, \& Samuel Adam Wathen. (2011). Statistical Techniques in Business and Economics with Connect.

Maiyarni, Reka, Susfayetti \& Misni Erwati. (2014). Pengaruh Profitabilitas, Ukuran Perusahaan, Likuiditas, dan Leverage Terhadap Pengungkapan Corporate Social Responsibility (CSR) Pada Perusahaan LQ-45 yang Terdaftar Di Bursa Efek Indonesia Periode 2009-2012. Jurnal Cakrawala Akuntansi. Universitas Jambi.

Nilasari, Ervika. (2013). Pengaruh Profitabilitas, Kepemilikan Institusional, Kepemilikan Asing dan Size Terhadap CSR Disclosure Perusahaan Tambang (Mining Sector) yang Melakukan Listing di Bursa Efek Indonesia Tahun 2010-2012. Universitas Dian Nuswantoro.

Nuraini, Nani., Effendi, Bahtiar \& Setiadi, Iwan. (2018). Corporate Governance dan Environmental Disclosure. Jurnal Ilmiah Akuntansi dan Pariwisata, 1(2), 19-30.

Perkasa, Anugerah. (2016). Polusi Udara: China Tutup 2.500 Perusahaan Penyebab Polusi. http://kabar24.bisnis.com/read/20160111/19/508647/polusi-udara-china-tutup-2.500perusahaan-penyebab-polusi.

Prakasa, Sila \& Astika, Ida Bagus Putra. (2017). Pengaruh Leverage, Profitabilitas, dan Kepemilikan Manajemen Pada Corporate Social Responsibility Disclosure 
Perusahaan Pertambangan. E-jurnal Akuntansi Universitas Udayana. Universitas Udayana, Bali.

Putri, Rindu Kurnia. (2015). Pengaruh Ukuran Perusahaan, Profitabilitas, Leverage, Likuiditas, dan Basis Kepemilikan Terhadap Corporate Social Responsibility Pada Perusahaan Pertambangan yang Terdaftar di Bursa Efek Indonesia (BEI) Periode Tahun 2012-2014. Universitas Riau, Riau.

Rahayu, Indun Prasetianti. (2016). Pengaruh Ukuran Perusahaan, Profitabilitas, Solvabilitas, dan Likuiditas Terhadap Luas Pengungkapan Corporate Social Responsibility (Studi Empiris Pada Industri Barang Konsumsi Tahun 2012-2014). Artikel Ilmiah Mahasiswa. Universitas Jember, Jember.

Samsiyah, Eka. (2014). Pengaruh Profitabilitas, Likuiditas, dan Leverage Terhadap Pengungkapan Tanggung Jawab Sosial Perusahaan. Jurnal Ilmu \& Riset Akuntansi. Sekolah Tinggi Ilmu Ekonomi Indonesia, Surabaya.

Wardhani, Devinta Galuh \& Sugiharto, Toto. (2013). Pengaruh Kinerja Keuangan, Ukuran Perusahaan, dan Kinerja Lingkungan Terhadap Intensitas Pengungkapan Pelaksanaan Tanggung Jawab Sosial Perusahaan Manufaktur yang Terdaftar di Bursa Efek Indonesia. Dalam Proceeding PESAT (Psikologi, Ekonomi, Sastra, Arsitektur \& Teknik Sipil). Universitas Gunadarma. 